Article

\title{
The Precarious Politics of Public Innovation
}

\author{
Hendrik Wagenaar ${ }^{1, *}$ and Matthew Wood ${ }^{2}$ \\ ${ }^{1}$ The Policy Institute at King's, King's College London, London, WC2B 6LE, UK; E-Mail: hendrik.wagenaar@gmail.com \\ 2 Department of Politics, University of Sheffield, Sheffield, S10 2TB, UK; E-Mail: m.wood@sheffield.ac.uk \\ * Corresponding author
}

Submitted: 21 November 2017 | Accepted: 5 February 2018 | Published: 3 April 2018

\begin{abstract}
This article argues that debates about public innovation among governance scholars risk essentialising the concept. Rather than recognise the inherently normative content of public innovation, some scholars have created taxonomies that conflate very different forms of 'innovation' in the public and private sectors, the latter of which is deeply contradictory to public values. We re-think public innovation as both a pragmatic process, a way of responding to developments in contemporary governance, and an inherently public and democratic practice. Our analysis addresses three points: who innovates; what is the object of innovation, and what are the effects of innovation? From this analysis we specify public innovation as both inescapable and democratically necessary to safeguard and promote the important values of public life.
\end{abstract}

\section{Keywords}

collaborative governance; democracy; essentialism; new public management; public innovation; unintended consequences

\section{Issue}

This article is part of the issue "Co-Producing Urban Governance for Social Innovation", edited by Liz Richardson (University of Manchester, UK).

(C) 2018 by the authors; licensee Cogitatio (Lisbon, Portugal). This article is licensed under a Creative Commons Attribution 4.0 International License (CC BY).

\section{Introduction}

Even a brief perusal of the public innovation literature demonstrates that, apparently, innovation in the public sector needs to be argued for. It is a common rhetorical trope to contrast innovation in the private and public sector, to consider the first inevitable, an intrinsic element of the market, and to provide a list of characteristics of government (bureaucratic, silos, monopoly or monopsony, absence of incentives) to argue why public innovation is supposed to be less likely (Potts \& Kastelle, 2010; Sørensen \& Torfing, 2011). On the face of it, these small rhetorical habits seem odd. Reform and innovation have always been an intrinsic part of public administration (Dunleavy \& Hood, 1994; Merritt \& Merritt, 1985; Moynihan, 2006; Weatherley \& Lipsky, 1977), from the days of Woodrow Wilson's The Study of Administration to Osborne and Gaebler's Reinventing Government. Moreover, the sheer size of the literature on public sector reform shows that the siren call of pub- lic innovation is hard to resist (for a historical study see Tolbert \& Zucker, 1983). In the advanced, administrative democracies of the West public innovation is a way of life, a professional default state. It's never difficult to find something amiss with the workings of the political and administrative system, and the environment in which governments operate keeps changing at dizzying speed. Who, then, does not want government agencies to be more efficient, responsive, technologically integrated, and designed on the basis of scientifically advanced, expert knowledge (Margetts, 2010, pp. 26-27)? Empirically, the affluent, well-organized administrative states of the West are the result of more than a century of patient, incremental, and sometimes radical, public innovation which combined changes in the organization of state bureaucracies, the direct production and delivery of services, and progressive fiscal policies, often supported by Social-Democratic, Christian-Democratic, and sometimes even Conservative politicians. The introduction of state-provided social insurance laws by Bismarck 
in 1883 , the remarkable program of Social-Democratic social housing construction and comprehensive urban planning in Vienna between 1918 and 1934, the introduction of the National Health Service in the UK in 1948, were all large-scale, highly successful examples of public innovation. Innovation in the public sector is, and has always been, as commonplace as in the business sector.

So why the slight rhetorical display of defensiveness in the recent academic literature? In arguing for 'collaborative innovation' for example, Hartley, Sørensen and Torfing (2013) assert the need to 'confront the myth that the market-driven private sector is more innovative than the public sector', while Torfing and Triantafillou (2016, p. 71) begin an empirical study of public innovation stating they aim 'to challenge the common understanding that innovation is something for the private sector only'. Rhetoric is the art of persuasion. So what does the reader, given the ubiquity of public innovation, need to be persuaded of? We will argue that public innovation is above all a political process, but that this has been under-emphasised in the literature. Most authors agree that public innovation contributes to public value. This implies that it stands in the service of sustaining and improving democratic life. Our theoretical argument is that in much public innovation literature (and practice) this democratic, political dimension is either downplayed or ignored altogether. This is because the starting point is to argue that innovation is a private sector phenomenon, and then assert that it can be a public one too (see for example, Sørensen \& Torfing, 2011, p. 846). We argue that this potentially leads to importing an understanding of innovation based largely on managerialist understandings of corporate efficiency and market value. Our argument here is informed by a certain impatience with the innovation 'industry' and its institutionalized amnesia: the powerful administrative-academic complex that creates the market for public innovation and produces the authoritative rhetoric to sustain it.

Our proposed solution is to begin by imagining innovation as a public good. Instead of starting by distinguishing public innovation from other types of innovation commonly found in the 'private' sector, we suggest innovation is an inherently public and democratic practice. Public innovation is both a ubiquitous feature of the public sector and democratically necessary to safeguard and promote the important values of public life. Our aim is to subject the idea and ideal of public innovation to critical interrogation, by exposing some of the assumptions that constrain its study, and to sketch a positive, democratic theory of public innovation. Such a theory is fashioned according to pragmatist principles of democratic experimentalism (Ansell, 2011; Healey, 2010; Honneth, 2017, Chapter 3; Smiley, 1999). Pragmatist democratic experimentalism entails, in the words of Christopher Ansell, "an open-ended process of refining values and knowledge" (Ansell, 2011, p. 8).

This article is organized in five sections. First, we show how existing justifications for public innovation tend to rest on precarious grounds, unless innovation is viewed as a democratic good. We then structure the second, third and fourth sections around three questions concerning public innovation: Who innovates? What is the object of innovation? What are the effects of innovation? This helps us to build a critical perspective on public innovation from multiple angles, focused on the actors, objects and results of innovation. These questions capture the originators of innovation (government, the corporate sector, citizens, societal organisations, transnational bodies), its object (ideas, organisations, behaviours, relations, technology), and the allimportant question of its intended and unintended effects, on government agencies, on officials, citizens, the budget, and on society. We then recap our argument and re-emphasise that if public innovation is not seen first and foremost as about democratic experimentation (Ansell, 2011), then academics (and practitioners) may repeat the mistakes created through decades of managerialism attempting to mimic private sector values in a public sector context.

\section{What Is Public Innovation?}

In general terms "public sector innovation is about new ideas that work at creating public value" (Mulgan, 2007, p. 6). These ideas need to be sufficiently large and enduring to constitute a recognisable break with past practices (Hartley, 2005, p. 27). They also need to be proactively pursued by the originating actor (Sørensen \& Torfing, 2011, p. 849). This is an exceedingly broad definition that includes many registers of political rule and public administration. 'New ideas' include new ways of organising public sector organisations, new ways of financing government (direct taxes versus user fees), new ways of delivering public services (public delivery versus privatisation or public-private partnerships), new ways of organizing the relationship between different agencies of the state (the centralization, devolution, or transnationalisation of governing powers), new ways of organising the relation between citizens and the state (interactive government, citizen participation), the introduction of new technologies (user-centred digital government), and so on (see also Mulgan, 2007). As we will see later, in the literature on public innovation this broad definition is perceived to have a universal quality in that it applies to all political systems and cultures.

An important element of public innovation consists of rhetoric. Not as a separate object or dimension of innovation (as in Hartley, 2005, p. 28), but as an integral dimension that pervades the very activity of innovation. Much public innovation is storytelling, acts of meaning making, of making sense of an overwhelming, unyielding and incomprehensible world. Through the allure of evocative rhetoric indeterminate ambitions are transformed into self-evident reform strategies that aim at convincing communities of their authority and legitimacy. For example, the introduction of corporate man- 
agement techniques in public agencies became a strategy to get "From Red Tape to Results" by "Creating a Government that Worked better and Costs Less" (Gore, 1993; Klijn, 2008). Or, by involving citizens in the design and implementation of government programs in so called "interactive government", "governments can obtain wholeness, coherence, and effectiveness, taking into account that governments no longer have the opportunity to direct, command and exercise control over their citizens" (Edelenbos \& van Meerkerk, 2016, p. 1). The suspicion that rhetoric is an essential performative dimension of public innovation is further supported by its follow-up. Hood and Dixon conclude, for example, that the debate about public sector reform "is surprisingly ideological" $(2015$, p. 5). Ironically, they also conclude that in the absence of serious evaluation studies "despite pious assertions about the importance of evaluation", even the evaluation of public sector reform has become part of the rhetoric (Hood \& Dixon, 2015, p. 5). The promise of reform trumps its results.

Much of the literature lists good reasons to make the case for the necessity of public innovation. Growing expectations from stakeholders, growing ambitions by elected officials and above all the complexity of a society that is dominated by interconnectedness and unpredictability (Bourgon, 2011; Sørensen \& Torfing, 2011). These are, however, almost always phrased in general terms. Torfing and Triantaffilou (2016, p. 1), for example, introduce the need for public innovation as a response to "political challenges such as demographic changes, increasing public health expenditure, unmet social demands, a growing number of wicked problems and the presence of numerous policy deadlocks". Sørensen and Torfing (2011, p. 847) refer to the need for public innovation arising out of "rising expectations about the quality, availability, and effectiveness of public services" and "growing ambitions in terms of the quality of public governance and its ability to solve social, economic, and environmental problems".

Societies, citizens and governments face real and serious challenges, such as climate change, falling wages and precarious labour contracts, the lack of affordable housing, crumbling infrastructure, the monopolistic dominance of FAMGA (Facebook, Apple, Microsoft, Google, and Amazon) and its impact on society and democracy, stagnating wages, tax evasion and avoidance by corporations and the rich, structural racism, gender bias, and so on. Most of these challenges exceed the imagination and governing capacity of governments and businesses and certainly warrant changes in the organization and process of governance. Our point, however, is a different one. Making these 'reasons for innovation' explicit also reveals their underlying political causes. In fact in quite a few of them, the state is as much part of the problem as the potential solution, bestowing upon the concept of 'public innovation' a less managerial and more politically charged, meaning. In addition to these functional reasons there are democratic reasons for continuous pub- lic innovation. Liberal democracy is always poised between stability and disruption (Griggs, Norval, \& Wagenaar, 2014, p. 27). It is an inherent quality of democracy that it will always fall short of its own high standards. As Griggs et al. (2014, p. 27) state: "the intrinsic fallibility of democracy places the individual in a complex ethical position. If we do not embrace a radical rejection of democracy because of its imperfections...we have no alternative left but to take responsibility and try to repair the imperfections or undo the shortcomings". In other words, public innovation is a defining characteristic of democratic governance, and, as the quote suggests, this ethical imperative extends to all citizens, not just political society. Therefore, public innovation ought to be viewed first and foremost as a public and democratic good, rather than a tool for problem solving (although it might be both in practice).

\section{Who Innovates in Public Innovation?}

An obvious answer to our first question is: government and its agencies. The elected officials and appointed administrators who design and implement policy and provide public services; the political-administrative complex of liberal elected democracy. A good example of this way of thinking is the work of Sørensen and her collaborators. Public service innovations have moved towards the centre of attention with governments at all levels as well as with Public Administration scholars (for an overview, see Agger, Bodil Krogh, \& Sørensen, 2015). This is particularly the case in Northwestern Europe (Agger et al., 2015, p. 3). Public service innovation takes place within the institutional framework of electoral liberal democracy. The decisions of politicians regarding the direction and priority of public services reflect not only what they "perceive to be right, just and valuable for society" (Sørensen, 2017 , p. 4) but also how they frame the relationship between citizens, or more precisely different groups of citizens, and the state, the relationship between the state and the corporate world, and the role and position of the nation state in the international order. Sørensen further argues for political innovation as a complementary to public sector innovation. Political innovation takes three forms: changes in "the institutional arrangements that regulate and authorize actors to govern a political community" ('polity'), changes in "the process through which policy-making takes place in practice within a given set of political institutions" ('politics'), and changes in "deliberate efforts to develop and promote new political visions, goals, strategies and policy programs" ('policy') (Sørensen, 2017, p. 4).

These programmatic statements are as revealing for what they leave out as for what they contain. As is clear from the above summary this work is characterised by a certain statist viewpoint. This might appear surprising as collaborative governance is nowadays presented as a distinct innovation paradigm in addition to market competition and organizational en- 
trepreneurship (Ansell \& Torfing, 2016; Hartley et al., 2013; Sørensen \& Torfing, 2011). However, the elaborations and examples of collaborative innovation demonstrate that collaboration is either a form of coordination between government agencies, public servants, intraorganizational networks of public managers, publicprivate networks, and internet-supported "crowdsourcing", a form of government-invited participation (Hartley et al., 2013, pp. 825-826). Innovation, Hartley et al. (2013) argue, is innovation in the public sector, and the public sector is defined in terms "of a collective effort to produce and deliver public value that is authorized or sponsored by federal, state, provincial, or local government" (Hartley et al., 2013, p. 822). However, this definition excludes some of the most interesting and significant forms of public innovation.

Vigoda (2002), for example, makes a plea for a move from responsiveness as a guiding value of public administration to collaboration. However, perhaps because of the contrast with the unidirectional, passive connotations of responsiveness, Vigoda (2002, p. 529) frames collaboration decidedly in democratic terms: "[collaboration] means negotiation, participation, cooperation, free and unlimited flow of information, innovation, agreements based on compromises and mutual understanding, and a more equitable distribution and redistribution of power and resources. According to this utopian analysis, collaboration is an indispensable part of democracy". Vigoda elaborates his inclusive definition of collaboration between governments and citizens by delineating a continuum of roles, ranging from 'citizens as subjects' to 'citizens as owners'. Vigoda's democratic definition of collaboration bears resemblance with the literature on deliberative systems (Mansbridge et al., 2012) and Type II democratic deliberation (Bächtiger, Niemeyer, Neblo, Steenbergen, \& Steiner, 2010). Both emphasize "a talkbased approach to political conflict and problem solving" and realize that for this to work these 'systems' must be both dispersed and democratically inclusive (Mansbridge et al., 2012, pp. 4-5). Similarly, Vigoda's continuum of citizen roles resembles the distinction between "government-induced" and "bottom-up interactive governance". The first is a form of citizen participation that is "strongly organized by governments"; the second involves all kinds of civic initiatives (Edelenbos \& van Meerkerk, 2016, p. 2).

At least since the late $19^{\text {th }}$ century days of Guild Socialism, citizens have been restless innovators, who, uninvited, organize themselves to manage their workplaces and neighbourhoods, produce social goods, and provide innovative ideas about the organization of society and the economy (Hirst, 1994, p. 105). They usually do this in socially and democratically innovative ways, transforming relations between individuals and social groups and empowering people who feel abandoned by the state (Claeys, 2013; Moulaert, Maccallum, \& Hillier, 2013, p. 40; Wagenaar, 2016). The innovative potential of these initiatives resides precisely in the fact that they originate in the "free spaces" of civil society (Evans \& Boyte, 1986). If we broaden our geographical horizon then we discover that Latin America is a breeding place for citizen-initiated innovations. As Avritzer notes, democratization in Latin America was spurred by "participatory publics". He describes a process, largely similar in most Latin American Countries in which community groups associate to address "contentious issues", subsequently transform "informal public opinion into a forum for public deliberation and administrative decision making", and finally design and negotiate with the authorities "institutional formats" for the outcomes of these participatory initiatives (Avritzer, 2009, p. 7). Avritzer emphasizes the role of participatory publics in providing "a democratic and participatory response to the problem of administrative complexity" (Avritzer, 2009, p. 137). Similarly, NGOs are in the business of public innovation, often setting agendas, designing solutions, formulating quality standards, and forging new forms of collaboration in areas such as fighting climate change, supporting refugees, and restricting worker exploitation in global production chains. The importance of NGOs is that they often operate at the level of global governance.

The above examples suggest there is more than a mere definitional issue at stake here. The statist bias in the definition of public innovation obscures from view some of the most important forms of public innovation and their effects. It draws a priori boundaries around the reach of democracy within public innovation, thereby arbitrarily limiting the possibilities for democratic renewal. Moreover, it can obscure more private sector-focused understandings of public innovation that drive a private takeover of the public sector (Bowman et al., 2013).

\section{What Is the Object of Innovation?}

There is a tendency in the public innovation literature to essentialise public innovation. Essentialism is the doctrine that "objects have certain essential properties, which make them one kind of a thing rather than any other" (Sayer, 2000, p. 82). The rhetorical impulse in the literature to define, categorize, and anatomise public innovation are, to our mind, ever so many attempts to essentialise it. While there is in principle nothing wrong with categorizing and finding (or declaring) similarities, for various reasons essentialism is risky in the social sciences. The first risk is that claims about sameness are mistaken. They may involve non-existent similarities or denials of significant differences. (Sayer, 2000, p. 83). For example, as we saw earlier, the definition of public innovation is so broad and involves so many different instigators, objects, goals, strategies and outcomes that one might genuinely question if it can be considered a coherent category in the first place. Taken to its extreme, the current rise of populism would fall within this definition of innovation. The purpose, or perhaps it is better to speak of the effect, of the habitual abstract definitions and categorizations is the use of the concept of 
public innovation outside its relevant context, its denotation as a clearly identifiable, stable and by implication, manageable, activity, that can be applied more or less unproblematically in different contexts. This kind of essentialisation shows itself, for example, in common vocabulary of 'design', 'tools', 'restructuring' and 'leadership' that suggest a requisite measure of control in instigating and implementing innovation (Edelenbos \& van Meerkerk, 2016; Hartley, 2005; although Hartley et al., 2013, are careful to emphasize the open-ended and contingent nature of public innovation).

There are different problems with these taxonomies that transcend mere definitional or linguistic habits. For one thing, it raises the issue of validity. Validity implies the accurate relation between thought and action, and at this point the rhetoric loses its innocence. To what extent are the characteristics of an innovation-New Public Management (NPM), interactive governance, government-driven democratization, participatory publics - an accurate reflection of what is happening 'on the ground'? The most likely answer is that the relation is at best tenuous. Ideals are indications of how we would like the reality in organizations, neighbourhoods or cities to look like. It requires considerable and sustained collective effort to get there. We will return to this later.

The second problem is moral equivalence. Every classification is a simile of the great taxonomies of Enlightenment botany and zoology. Taxonomy is meant to be morally neutral; the genus and species are entries in the book of nature, wholly outside ethics. However, for three reasons, this ethical quarantine cannot be transferred to public innovation. First, public innovation is by definition an attempt to improve the world of governance and public administration by making it more efficient, equitable, responsive, integrated, innovative or democratic. These are big values and some forms of innovation will realize these values better than others. Second, some realizations will promote some values over others, creating contradictions in the relative weighing of values in the public domain (Margetts, 2010, p. 41). For example, in many public service systems the emphasis on economic efficiency in the context of NPM has favoured budgetary restraint and public competition over service coordination and deliberation (Wagenaar, Vos, Balder, \& van Hemert, 2015). Or, the emergence of innovative and responsive citizen cooperatives has eroded universalism in public service delivery (Wagenaar, 2015). Third, implying moral equivalence ignores the power differentials between actors in the public innovation arena. Much public innovation involves the transfer of rights, money and powers by public actors to corporate actors. This is of a wholly different order than sharing power with citizen groups. We will return to this point when we discuss unintended effects.

However, apart from problems of essentialism, the question remains: What, in concrete situations of public administration, is the object of public innovation? Is it more effective, more efficient service delivery? Better coordination between government agencies? More inclusive local decision-making? A change in the relation between officials and citizens? A smaller state? The institutionalization of participatory governance? What exactly is it that needs to change? Let's look at a somewhat extended example.

NPM is as good an example as any of a public innovation. With hindsight, NPM is arguably the most significant and widespread public innovation of the last 30 years. Its ethos and vocabulary of corporate managerialism has enthralled governments around the world. Its repertoire of techniques-performance indicators, outsourcing, performance-related pay, auditing, consumer boards-has changed the face of public service delivery in many countries (Hood \& Dixon, 2015). Although it is generally described as an innovation in public administration, its objectives of radically reconfiguring the relationship between politicians, officials and the market are deeply political. The origins of NPM have to be found in the writings on public choice, a blend of dysphoric critique of big government and the application of microeconomic theory to public administration (Buchanan, 1988; Niskanen, 1971). For 15 years these ideas were debated and developed in relative quiet until Osborne and Gaebler published their famous book which functioned as an 'instruction manual' for NPM. In these 15 years the economic-political order underwent a profound neoliberal transformation (Crouch, 2011; Streeck, 2017) that prepared the ground for the ideas of NPM to be put into effect. In hindsight, the time was right; a policy window had opened for the ideas of Niskanen, Buchanan, Osborne and Gaebler. In clear, concise language, unencumbered by economic theory, Osborne and Gaebler laid out a blueprint for a government that promised a smaller yet more effective government than is required by the direct delivery state. It contained a catchy 'logo' ('steering not rowing') and concrete instructions of how to reorganize the public sector according to corporate and market principles (Osborne \& Gaebler, 1992). Numerous 'Third Way' social-democratic governments who saw NPM as a solution to the conservative challenge that 'government is the problem, not the solution', enthusiastically adopted their ideas. NPM contained the promise to shrink government outlays, maintain a required level of service to the public, and sport a modern, rational, decisive image by adopting corporate management techniques. "Creating a government that worked better and cost less" (Gore, 1993; Hood \& Dixon, 2015), rapidly acquired the status of a valence idea. The result was a reframing, a resetting of expectations, of what citizens can expect from the state, a reconfiguration of state relations with citizens and corporate actors, an extension of corporate influence in civil and personal life spheres, and a hollowing out of democratic accountability through an acceleration of the privatization of public services.

We could probably tell a similar tale about the vicissitudes of three decades of interactive government (Voor- 
berg, Bekkers, \& Tummers, 2015). The point is not about the specifics but the plot of the narrative. Convenient labels such as 'NPM', 'interactive government', or 'public value management' suggest more ideological and strategic unity than is warranted. Public innovation is more a social movement or a historical trend-contingent, emergent-than a coherent program. Christopher Hood and Ruth Dixon did us a great service by compiling a detailed overview of thirty years of public innovation in the UK. Theirs is a story of restless improvements and innovations that span the whole gamut from political restructuring to changes in delivery systems. Devolution to regional parliaments is followed by the (financial) autonomy of local government. The shape and functioning of the administrative bureaucracy is shaken up by the creation of independent regulators and political civil servants. Many bureaucracies were split up into agencies and then consolidated again. At the same time state public sector bureaucracies introduced corporate management arrangements. A large number of state companies and agencies were privatized; core public services, such as public transport, health, adult care, and energy and water provision, have been contracted out to private sector companies (Hood \& Dixon, 2015, pp. 20-43). With some effort we could probably put together a similar story of incessant innovation in countries such as the Netherlands and Denmark (with more emphasis on interactive governance and government-initiated citizen participation). The birth and worldwide adoption of NPM or interactive government show similarities to the contingent agenda setting processes as described by John Kingdon where parallel streams of ideas, ideologies, and political developments interact in unpredictably ways while policy entrepreneurs restlessly circle the halls of government trying to pounce on the right moment (2011). The key point is that in all these instances most of these innovations are instigated without being part of a larger plan. They are reactive and pragmatic; their rationality is largely after the fact.

Public innovations are not straightforward applications of an impulse to improve the functioning of our administrative apparatus, as most definitions of public innovation imply. Instead they are the contingent outcomes of human agency, ideological enthusiasm, strategic one-upmanship, and historical development. They try to solve a locally or nationally bounded problem, their content inspired by some ideology (of a better and smaller government, as in the case of NPM), an opportunity for strategic advantage (as in Third Way innovations), a more responsive and democratic form of governance (as in the case of interactive or collaborative governance), a reshuffling of the roles and responsibilities of state, corporations and civil society in delivering public services, or a mix of the above, with little anticipation of, and interest in, the future effects of the change, but with a keen eye on presenting them as rational, reasoned improvements of government practices. Some of these local innovations aggregate into a more coherent movement, to which a professor or policy entrepreneur attaches a label and a storyline that appeals to a receptive audience.

\section{What Are the Effects of Public Innovation?}

Clearly, many good things have followed from the efforts of politicians and officials to improve the functioning of government. The high quality of life in Northwestern European democracies testifies to that. But, as that shrewd observer of public policy, Aaron Wildavsky, wrote 40 years ago, policy is its own cause (Wildavsky, 1979). Why is that? The answer, in today's terms, is because every policy space is a complex system, where interaction effects and positive and negative feedback create wholly unpredictable system dynamics that quickly overwhelm policy makers (Teisman, van Buuren, \& Gerrits, 2009; Wagenaar, 2007; Waldrop, 1992). Most of these "emergent effects" are unforeseen; some are positive (Hood \& Dixon, 2015) but many of them undesired by at least some of the relevant stakeholders $(6,2001)$. Given the high risk of unforeseen negative consequences following interventions in the social order, public innovation aggravates that risk by its ambition to overhaul whole systems of public administration.

The above point makes another of Wildavksy's observations particularly pertinent: the Law of Large Solutions. "The Law of large Solutions implies that the greater the proportion of the population involved in policy problem, and the greater the proportion of the policy space occupied by the supposed solution, the harder it is to find a solution that is not its own worst problem" (Wildavsky, 1979, p. 63). Our position is that public innovations have real world consequences for citizens, communities, third sector organizations, public sector employees, and local administrations. They define their relationship to the state, and the possibilities for just and effective governance and service delivery. Moreover, the types of public innovation are not morally neutral, the effects of innovation can and should be assessed within the normative framework of Western democracy, and as a result of such assessments we need to distinguish between effective and less effective innovations (Hartley, 2005) as well as between more and less desirable forms of public innovation. For reasons that are rooted in the two preceding challenges, we argue that the outcomes of public innovation should occupy the top of the public innovation agenda.

In one of the few systematic studies of the effects of administrative modernization, Hood and Dixon (2015) emphasize the diversity of impacts. What effects can we expect? First, and most straightforwardly, history is full of political innovations that served ignoble or repressive purposes. The discovery and perfection of modern media - at the time wireless radio broadcasts - as a tool for propaganda by the National-Socialist regime is just one example. The use of advanced search and data storage technology for the mass surveillance of citizens is another. On a much smaller scale, Wagenaar, Amesberger 
and Altink (2017) report the use of innovative coordination tools in local administration that are used to entrap sex workers. Governments hitch on to new technology to expedite the process of government, both for benign and pernicious purposes. On the basis of perceived threats to its integrity, every state divides its population in deserving and undeserving groups (Edelman, 1988), and it deploys its full panoply of discourse, technique and innovation to check, contain or, ultimately, eliminate such groups (Wagenaar, 2015).

A second possibility is the absence of desired effects. Although the reform initiative is genuine, and stakeholders engage enthusiastically, the outcome may nevertheless be disappointing. This is the pattern of much invited participation of citizens in the design, implementation and delivery of policy programs. Although there are some spectacular examples of successfully institutionalized participatory efforts (the Porto Alegre participatory budgeting initiative is the most cited showcase), many of them have disappointing outcomes. The reasons are manifold. Avritzer ascribes the success of the Porto Alegre experiment to a favourable confluence of political circumstances. Similar experiments in Belo Horizonte and Sao Paolo were much less successful (Avritzer, 2009). In our study of governance-driven democratization in The Hague we encountered many small organizational obstacles, many of them the result of earlier NPM reforms, that prevented the voice of citizens to be heard in municipal agencies (Wagenaar, van Schijndel, \& Kruiter, 2010). Sometimes it is the government's obligation to protect constitutional values and procedures that constrains officials' possibilities to transfer executive power to citizen groups. For example, the disappointing results of a more participatory approach to social care in the Netherlands, is credited to the government's legally prescribed obligation to regulate and its inability to refrain from micromanaging citizen initiatives (Linders, Feringa, Potting, \& Jager-Vreugdenhil, 2016). In both examples the explanation for the disappointing outcomes of these innovations resided in the systematic-structural conditions that drove the public sector in those particular locations.

But even well intended public innovations generate negative unintended consequences (Hartley, 2005, p. 32; Hood \& Dixon, 2015). For example, as with every policy intervention, the publicized benefits of an innovation might never materialize. After a painstaking and difficult compilation of data on the outcome of NPM reforms, Hood and Dixon conclude that in the UK "running costs rose substantially in absolute terms over thirty years, while complaints soared" (2015, p. 178). What drove up cost was not so much the wage costs of civil servants but the "outsourced' elements of running costs, even though outsourcing had tended to figure large in standard recipes for greater efficiency" (2005, p. 178). Hood and Dixon conclude that "this is not exactly what 'it said on the tin' of all those grandiloquent reform makeovers aimed at containing costs and improving administration for citizens" (2005, p. 178).
When Hood and Dixon conclude that the costs of outsourcing had driven up the costs of government in the UK, they overlooked a number of important negative unintended consequences of outsourcing. Bowman and his colleagues at the Centre for Research on SocioCultural Change at the University of Manchester have done for outsourcing what Hood and Dixon did for NPM. In a careful collection and analysis of hard-to-find data they traced the effects of contracting out. First, Bowman et al. (2015) estimate the annual turnover of the "public service industry" in the UK at between $£ 80$ and $£ 100$ billion, the fastest growing segment in local government (Bowman et al., 2015, p. 3). The more important question perhaps is what effect this frenzy of outsourcing has on the quality of government, and for that matter, of democracy and society. In summary, the effects are a massive transfer of public money to private corporations, a serious decline of the availability and quality of essential services, the intrusion of the extortionist practices of the finance industry into the public sector, and the erosion of democratic influence and accountability. For example, contracting out is sold as a cost saving measure that simultaneously increases the quality of service delivery. If that claim is made true then a $f 100$ billion outlay (the total of pubic service contracts to corporate providers) is public money well spent. However, Bowman et al. (2015) reveal a pattern of excessive profit-taking, without risk, at the expense of the taxpayer and the workforce. The reasons are that the return on capital for supplying services to the state is much higher than that of suppliers to private industry (Bowman et al., 2015, p. 45), the industry's ability to obtain franchises that amount to a "Iocal monopoly for the multi-year duration of the contract" (Bowman et al., 2015, p. 46), and the routine strategy of private providers to save costs by cutting wages and hollowing out labour contracts (Bowman et al., 2015, p. 53).

What about the quality of the outsourced services? Unfortunately the picture is equally dismal. Using complaints to the ombudsman and the number of judicial review applications as their indicator of service quality, Hood and Dixon find that both have increased over the thirty years of NPM innovation in the UK. Bowman et al. (2015) point to a pattern of routine failure in which the co-dependent state and corporate sector shift the blame to a weak surveillance and monitoring system and a supposed lack of knowledge within the core executive (Bowman et al., 2015, p. 30). Perhaps the most toxic effect of outsourcing is the colonization of the public sector by the financial logic of corporate conglomerates. Most private vendors are part of an opaque conglomerate of holding companies and investment vehicles. These conglomerates are part of the world of equity markets and global finance. Outsourcing companies are forced into a game of debt-funded acquisitions to boost shareholder value. The investment firm that owns the outsourcing firm provides the debt for the acquisitions and sets artificially high margins that are booked as internal debt and weaken the balance sheet of the subsidiary. Com- 
monly the subsidiary pays out high dividends to the parent company, which are financed by loans that raise the debt level of the outsourcing company, lower its earnings before interest and tax, and effectively result in reduced corporate tax liabilities (Bowman et al., 2015, p. 87). The upshot of this is a huge transfer of taxpayer's money to the owners and shareholders of the outsourcing corporates and their parent companies.

\section{The Precarious Politics of Public Innovation}

What have we learned about public innovation, as it unfolds 'on the ground'? We draw four lessons from the argument and examples in the preceding sections. The fact that public innovation happens everywhere, at all times and with different intentions, as we saw above, has two important implications for the academic analyst. First, it changes the very idea of innovation. Innovation is less 'intentional development' and more practical, pragmatic, and usually local, problem solving. Recognizing the pragmatic nature of public innovation, Sørensen and Torfing speak of a "complex, nonlinear, and often messy" process (although they do project four distinct phases onto this "messy" process; 2011, p. 852). The language of practice is helpful here. If a policy intervention is seen as a projection of intention into an unknown, and often unknowable, future, then the effects of that intervention are the result of backtalk, the agency of the material-economic-political world. Most policy sectors, as we have seen, are subject to the Law of Large Solutions. The world has a complexity that far exceeds human cognitive capacities. Not surprisingly, the effects of an innovative effort differ from the original promises and expectations; they fall short, are seen as disappointing or, in case of perverse unintended consequences, as a policy failure. This gives rise to many different and well-known political responses: a reformulation of goals, blame shifting, or controlling the political message through spin doctoring (Bowman et al., 2015; Hood \& Dixon, 2015, p. 11; Stone, 1997, p. 190). In some cases, officials embark on an intervention that purports to improve the way policy is made or administration organized. This, often with hindsight, is recognized as a public innovation, but for the purposes of this analysis, we interpret it as a reaction to the resistance that was provoked by the original policy intervention. In practice terms: the resistance "denotes a failure to capture the agency of the world" and the innovation represents an accommodation to come to terms with this resistance. The language is Pickering's (1995), who pictures this reciprocal process of intervention, resistance and accommodation as a continuous, and inescapable, dialectic (1995, p. 23).

It is at this point that another important lesson from the preceding analysis weighs in. In the realm of politics and governance the dialectic of resistance and accommodation is a dispersed interactive process in which an unknown number of actors struggle with the agency of the world and of each other. This subjects this dialectic to endless processes of gaming and trying to get the better of the other's interventions. All these micro-activities are ever so many moments of accountability, where actors assess the consequences of the change that is imposed on them and decide to support, resist or adapt to it (Nowotny, Scott, \& Gibbons, 2003). Eventually, this dance of resistance and adaptation results in unforeseen and unforeseeable outcomes, as its endless chain of action and reaction ripples through the political and social sphere. This is where intention and outcome meet. One actor's innovation is another actor's invitation to move into a field and neutralize a threat to one's dignity, freedom, cherished life, work routines, moral worth or community cohesion, or redefine it as a business opportunity and extract unjustifiable profits. So, the second lesson is that we should not discuss public innovation without taking its outcomes into consideration. This implies that the analyst, in addition to, or instead of, acting as an advocate, must act as a critical interpellator, similar to the examples we gave in section two. Critical interpellator implies that the analyst collects data and indicates where they are not available, follows the money (Bowman et al., 2015) to the point where the strategic decisions are made, and traces the effects of an innovation to the point where the power to decide resides and the gains of the innovation are harvested.

Third, the examples reveal another important, this time substantive, lesson about public innovation: the fallacy of moral equivalence. In section three we were critical of a certain essentialising tendency that we observed in some of the literature on public innovation. As we have seen, public innovation is defined so broadly and harbours such a wide variety of interventions within its conceptual boundaries (Hartley, 2005) that it is risky to ascribe significant commonalities to it that define the category of innovation in a uniform and coherent way. As we saw when discussing the outcomes of innovation, one actor's innovation is another actor's loss. Different actors in the intervention enterprise have different interests and intentions. For example, public innovations that involve corporate actors run a serious risk of being compromised by the logic of profit and shareholder value. Several mechanisms create this corrosive influence. Not only are public officials no match for the deep resources and expertise of corporate actors, but also the public prestige and the lure of generous remuneration of the corporate sector are hard to resist. Apart from the ethically dubious spectacle of ex-government officials taking lucrative jobs in the very industries they once oversaw, this a priori favourable attitude towards business explains some of the dynamics that led to the fatal codependence between government and the public service corporations that Bowman et al. observed (2015, p. 7). Once companies have obtained the lucrative franchises, the loss of the organizational and intellectual resources for adequate service delivery proceeds quickly. On a deeper level, the values and practices of the corporate world are inimical to those of the public sector. 
This has serious consequences for the public sector as we have seen. Not only does it lead to a transfer of tax payers' money to the corporate sector, but also to a decline in the quality of service delivery, the replacement of social by financial innovation, a hollowing out of administrative expertise, and an erosion of political transparency and accountability.

Moreover, this transparency and accountability deficit has acute implications for public engagement in civic life. Colin Crouch's (2004) Post-Democracy captures how corporate influence in policy making, institutionalized through delegation of important resource decisions to unelected agencies, hollows out the public sphere (see also, Wolin, 2008). Since citizens can no longer see why they ought to engage with public debate, they retreat, either into the private activity of consumerism, or to 'everyday' forms of protest and social media fuelled "connective action" (Bennet \& Segerberg, 2013). This results in a growing inequality between those who are able to navigate the complex structures of distributed governance and service delivery and can make their voices heard (the well connected higher middle class), and those who do not and have become marginalized from crucial decisions that impact on their lives (the disconnected 'precariat'). Public 'innovations' can be utilized to empower some more than others in public management, and the already well-connected often accumulate more power, while the poorly connected lose out to a greater degree.

Perhaps most importantly, the colonization of the public sector by corporate values and practices results in a loss of the very spirit of the public sector. In proximate terms this amounts to a loss of public value; in more distal, but ultimately more significant terms, in the loss of a moral vision of a just and equal society in which everyone regardless of their ethnicity, religion, gender or economic position, finds security and the concomitant possibility to develop and improve themselves. In terms of democratic governance, public and corporate interests do not mix, whether it concerns health care, public transport, libraries, prisons or universities. The money nexus, with its core values of efficiency and 'value for money', drives out most that is central to the values and practice of the public sector and, ultimately, of democracy.

Where does this leave us with regard to the ideal and prospects for public innovation? We do not deny, of course, the necessity, and possibility, of improvement in collective decision-making and service delivery, but we frame this process differently. What we propose is a process of guided change that is much more democratically embedded, distributed, pragmatic, interactive and, therefore, precarious. Wildavsky's advice to circumvent the Law of large Solutions is a form of incrementalism. ("the way to solve large social problems is to keep them small"; Wildavsky, 1979, p. 63). In this spirit we argue for a pragmatist approach to public innovation (Ansell, 2011; Bourgon, 2011). 'Innovation' is intrinsic to practices of governance. It can be triggered by ideals or failure, by crises, challenges or political expedience. But no matter its impetus, it always involves a subsequent alignment of intention and consequence. Innovation is dispersed and socially distributed. Even if an identifiable state actor triggers an innovation, it evolves through the actions and reactions of a large number of actors. It is not uncommon, as experiments in collaborative governance demonstrate, that innovations emerge in the civic sphere, and transfer to political society. In such a situation a pragmatist approach to innovation involves three "generative conditions" that facilitate 'evolutionary learning": a "problem-driven perspective", reflexivity about the trajectory of our interventionist experiences, and the necessity of deliberation, or the reciprocal communication that is necessary for "adjudicating differences" between different actors, producing jointly constructed meanings and coordinating joint action (Ansell, 2011, pp. 11-12).

\section{Acknowledgments}

We are grateful to the anonymous reviewer whose detailed, critical reading of the original manuscript provided us with many valuable suggestions for improvement. Matthew Wood acknowledges funding from the ESRC Future Research Leaders project New Political Spaces.

\section{Conflict of Interests}

The authors declare no conflict of interests.

\section{References}

6, P. (2001). When forethought and outturn part: Types of unanticipated and unintended consequences. In $\mathrm{H}$. Margetts, P. 6, \& C. Hood (Eds.), Paradoxes of modernization. Unintended consequences of public policy reform (pp. 44-63). Oxford: Oxford University Press.

Agger, A., Bodil, D., Krogh, A. H., \& Sørensen, E. (Eds.). (2015). Collaborative governance and public innovation in Europe. Sharjah: Bentham Science Publishers.

Ansell, C. K. (2011). Pragmatist democracy. Evolutionary learning as public philosophy. Oxford: Oxford University Press.

Ansell, C., \& Torfing, J. (Eds.). (2016). Public innovation through collaboration and design. Abingdon: Routledge.

Avritzer, L. (2009). Participatory institutions in democratic Brazil. Baltimore, MD: The Johns Hopkins University Press.

Bächtiger, A., Niemeyer, S., Neblo, M., Steenbergen, M. R., \& Steiner, J. (2010). Symposium: Toward more realistic models of deliberative democracy disentangling diversity in deliberative democracy: Competing theories, their blind spots and complementarities. The Journal of Political Philosophy, 18(1), 32-63.

Bennet, W. L., \& Segerberg, A. (2013). The logic of connective action. Digital media and the personalization of contentious politics. Oxford: Oxford University Press. 
Bourgon, J. (2011). A new synthesis of public administration: Serving in the $21^{\text {st }}$ century. Montreal: McGillQueen's University Press.

Bowman, A., Ertürk, I., Folkman, P., Froud, J., Haslam, C., Johal, S., .. . Williams, K. (2015). What a waste. Outsourcing and how it goes wrong. Manchester: Manchester University Press.

Buchanan, J. (1988). Market failure and political failure. Cato Journal, 8(1), 1-13.

Claeys, M. (2013). Stilstand. Over machtspolitiek, betweterbestuur and achterkamerdemocratie. Het Oosterweeldossier [Stagnation. On power-politics, know-all government, and backroom-democracy. The Oosterweel Files]. Leuven: Uitgeverij van Halewijck.

Crouch, C. (2004). Post-democracy. Cambridge: Polity Press.

Crouch, C. (2011). The strange non-death of neoliberalism. Cambridge: Polity Press.

Dunleavy, P., \& Hood, C. (1994). From old public administration to new public management. Public Money \& Management, 14(3), 9-16.

Edelenbos, J., \& van Meerkerk, I. (2016). Introduction: Three perspectives on interactive governance. In J. Edelenbos \& I. van Meerkerk (Eds.), Critical reflections on interactive governance. Self-organization and participation in public governance (pp. 1-29). Cheltenham: Edward Elgar.

Edelman, M. (1988). Constructing the political spectacle. Chicago, IL: The University of Chicago Press.

Evans, S. M., \& Boyte, H. (1986). Free spaces: Sources of democratic change in America. New York, NY: Harper Collins Publishers.

Gore, A. (1993). From red tape to results. Creating a government that works better and costs less. (Report of the National Performance Review). Washington, DC: Government Printing Office.

Griggs, S., Norval, A., \& Wagenaar, H. (2014). Introduction: Democracy, conflict and participation in decentred governance. In, S. Griggs, A. Norval, \& H. Wagenaar (Eds.), Practices of freedom: Democracy, conflict and participation in decentred governance (pp. 1-38). Cambridge: Cambridge University Press.

Hartley, J. (2005). Innovation in governance and public services: Past and present. Public Money and Management, 25(1), 27-34.

Hartley, J., Sørensen, E., \& Torfing, J. (2013). Collaborative innovation: A viable alternative to market competition and organizational entrepreneurship. Public Administration Review, 73(6), 821-830.

Healey, P. (2010). Making better places. The planning project in the twenty-first century. Houndmills and Basingstoke: Palgrave Macmillan.

Hirst, P. (1994). Associative democracy: New forms of economic and social governance. Cambridge: Polity Press.

Honneth, A. (2017). The idea of socialism. Cambridge: Polity Press.

Hood, C., \& Dixon, R. (2015). A government that worked better and cost less? Evaluating three decades of reform and change in UK central government. Oxford: Oxford University Press.

Kingdon, J. (2011). Agendas, alternatives and public policies (2nd ed.). New York, NY: Harper Collins.

Klijn, E. H. (2008). It's the management stupid! On the importance of management in complex policy issues. Den Haag: Lemma.

Linders, L., Feringa, D., Potting, M., \& Jager-Vreugdenhil, M. (2016). Tussen regels en vertrouwen. Veranderende rollen in de verzorgingsstaat [Between rules and trust. Changing roles in the welfare state]. Amsterdam: van Gennep.

Mansbridge, J., Bohman, J., Chambers, S., Christiano, T., Fung, A., Parkinson, J., . . . Warren, M. E. (2012). A systemic approach to deliberative democracy. In J. Parkinson \& J. Mansbridge (Eds.), Deliberative systems. Deliberative democracy at the large scale (pp. 1-27). Cambridge: Cambridge University Press.

Margetts, H. (2010). Modernization dreams and public policy reform. In H. Margetts \& C. Hood (Eds.), Paradoxes of modernization. Unintended consequences of public policy reform (pp. 17-44). Oxford: Oxford University Press.

Merritt, R. L., \& Merritt, A. J. (1985). Innovation in the public sector. Thousand Oaks, CA: Sage Publications.

Moulaert, F., Maccallum, D., \& Hillier, J. (2013). Social innovation: Intuition, precept, concept, theory and practice. In F. Moulaert, D. MacCallum, A. Mehmod, \& A. Hamdouch (Eds.), The international handbook on social innovation (pp. 13-25). Cheltenham: Edward Elgar.

Moynihan, D. P. (2006). Managing for results in state government: Evaluating a decade of reform. Public Administration Review, 66(1), 77-89.

Mulgan, G. (2007). Ready or not? Taking innovation in the public sector seriously. London: Nesto.

Niskanen, W. (1971). Bureaucracy and representative government. Chicago, IL: Aldine Atherton.

Nowotny, H., Scott, P., \& Gibbons, M. (2003). 'Mode 2' revisited: The new production of knowledge. Minerva, 41(3), 179-194.

Osborne, D., \& Gaebler, T. (1992). Reinventing government. How the entrepreneurial spirit is transforming the public sector. New York, NY: Perseus Books.

Pickering, A. (1995). The mangle of practice. Time, agency, and science. Chicago, IL: The University of Chicago Press.

Potts, J., \& Kastelle, T. (2010). Public sector innovation research: What's next? Innovation, 12(2), 122-137.

Sayer, A. (2000). Realism and social science. Thousand Oaks, CA: Sage Publications.

Smiley, M. (1999). Pragmatic inquiry and democratic politics. American Journal of Political Science, 43(2), 629-647.

Sørensen, E. (2017). Political innovations: Innovations in political institutions, processes and outputs. Public Management Review, 19(1), 1-19. 
Sørensen, E., \& Torfing, J. (2011). Enhancing collaborative innovation in the public sector. Administration and Society, 43(8), 842-863.

Stone, D. (1997). Policy paradox. The art of political decision making. New York, NY: W. W. Norton \& Company.

Streeck, W. (2017). Buying time. The delayed crisis of democratic capitalism (2nd ed.). London: Verso.

Teisman, G., van Buuren, A., \& Gerrits, L. (Eds.). (2009). Managing complex governance systems. Abingdon: Routledge.

Tolbert, P. S., \& Zucker, L. G. (1983). Institutional sources of change in the formal structure of organizations: The diffusion of civil service reform, 1880-1935. Administrative Sscience Quarterly, 28(1), 22-39.

Torfing, J., \& Triantafillou, P. (2016). Public innovations around the world. In J. Torfing \& P. Triantafillou (Eds.), Enhancing public innovation by transforming public governance (pp. 71-94). Cambridge: Cambridge University Press.

Vigoda, E. (2002). From responsiveness to collaboration: Governance, citizens and the next generation of public administration. Public Administration Review, 62(5), 527-540.

Voorberg, W. H., Bekkers, V. J. J. M., \& Tummers, L. G. (2015). A systematic review of co-creation and coproduction: Embarking on the social innovation journey. Public Management Review, 17(9), 1333-1357.

Wagenaar, H. (2007). Governance, complexity and democratic participation: How citizens and public officials harness the complexities of neighbourhood decline. American Review of Public Administration, 37(1), 17-50.

Wagenaar, H. (2015). Governance-driven conflict: Policy, reason of state and authoritarian governmentality. In E. Gualini, J. Mourato, \& M. Allegra (Eds.), Conflict in the city: Contested urban spaces and local democracy (pp. 112-132). Berlin: Jovis Verlag.

Wagenaar, H. (2016). Democratic transfer: Everyday neoliberalism, hegemony and the prospects for democratic renewal. In J. Edelenbos \& I. van Meerkerk (Eds.), Critical reflections on interactive governance (pp. 93-119). Cheltenham: Edward Elgar.

Wagenaar, H., Vos, J. J., Balder, C., \& van Hemert, A. M. (2015). Overcoming conflicting logics of care and justice: Collaborative innovation in dealing with habitual offenders in the Netherlands. In A. Agger, B. Damgaard, A. H. Krog, \& E. Sørensen (Eds), Collaborative governance and public innovation in Northern Europe (pp. 111-133). Sharjah: Bentham Science Publishers.

Wagenaar, H., Amesberger, H., \& Altink, S. (2017). Designing prostitution policy: Intention and reality in the sex trade. Bristol: Policy Press.

Wagenaar, H., van Schijndel, M., \& Kruiter, H. (2010). Bewonersparticipatie en veiligheid. Tussen droom en daad in een complexe bestuurlijke context [Resident participation and security. Intention and reality in a complex governance context]. The Hague: Leiden University.

Waldrop, M. M. (1992). Complexity. The emerging science at the edge of order and chaos. New York, NY: Simon \& Schuster.

Weatherley, R., \& Lipsky, M. (1977). Street-level bureaucrats and institutional innovation: Implementing special-education reform. Harvard Educational Review, 47(2), 171-197.

Wildavsky, A. (1979). Speaking truth to power: The art and craft of policy analysis. Piscataway, NJ: Transaction Publishers.

Wolin, S. S. (2008). Democracy inc. managed democracy and the specter of inverted totalitarianism. Princeton, NJ: Princeton University Press.

\section{About the Authors}

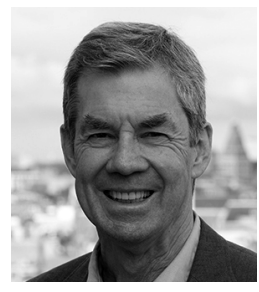

Hendrik Wagenaar is currently senior advisor to the Policy Institute at King's College London and the Paul Lazarsfeld visiting professor at the University of Vienna. He publishes about participatory democracy, interpretive policy analysis, prostitution policy and practice theory. He is author of Meaning in Action: Interpretation and Dialogue in Policy Analysis (Routledge, 2011), and co-editor of the seminal Deliberative Policy Analysis (Cambridge, 2003). He recently published Designing Prostitution Policy: Intention and Reality in Regulating the Sex Trade (Policy Press, 2017).

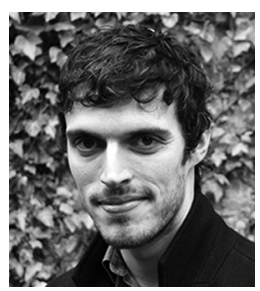

Matthew Wood is a Lecturer in Politics at the University of Sheffield and ESRC Future Research Leaders fellow. He has published widely on issues of co-production, legitimacy and depoliticization in local, national and transnational governance. His most recent edited book, Anti-politics, Depoliticization and Governance, was published in 2017 by Oxford University Press. 